УДК: [78.071.2: 792.028]: 001.891.3

DOI:

Тетяна Гердова, кандидат мистецтввознавства, стариий викладач кафедри акторської майстерності та дизайну, Запорізького національного університету

\title{
ПРО СПІЛЬНІ ПРИНЦИПИ ТЕАТРАЛЬНОГО ТА МУЗИЧНОГО МИСТЕЦТВ
}

У статті обтрунтовано спільні принципи театрального й музичного мистецтвв - герменевтична природа та прочесуальність. Визначено потенційну базу вдосконалення художньої виразності просодіі літературної основи драматичної вистави. Виявлено специфіку виразних засобів музичної мови і вербальної, значення вказаної специфічності в організації художньої цілісності драматичної вистави. Спільні для музичного і театрального мистецтв іманентні властивості розглянуто як основу інтерпретаціі семантичного значення окремих елементів художнього тексту.

Ключові слова: музичне мистецтво; театрально-драматичне мистецтво; процесуальність; засоби виразності; вербальний текст; ритм.

Лim. 14.

Tetyana Herdova, Ph.D.(Study of Art), Senior Lecturer of the Acting Skills and Design Department Zaporizhzhya National University

\section{ABOUT THE GENERAL PRINCIPLES OFTHEATRE AND MUSIC ARTS}

The article is devoted to the problem of the expressiveness of the prosodic-sound component of a dramatic performance. This problem is part of a more general task of updating and improving the creative arsenal of performers. Enriching and expanding means of expressiveness is always an internally urgent process, for which the analytical approach in determining the potential base is essential. The urgency of searching for new artistic ideas and corresponding expressive means is connected with the creation of artistically significant productions, with the tasks of activating the impact on the viewer, the approval of artistic and value orientations.

The purpose of the article is to substantiate the potential basis for improving the artistic expressiveness of a dramatic performance; to define the common points of two areas of artistic creative activity - musical and theatrical; the possibility of using the expressive means of music language in the artistic integrity of the dramatic performance. The methodology of the researchconsists in revealing the possibility of extrapolation some points of the music content's theory of A. Kudryashov on the situation of drama performance. The theory of integrated analysis of a literary work and the theory of the art prose's rhythm of M. Girshman rendered an opportunity to reveal significance and functioning some of the verbal elements in artistic integrity. The principles of the integrated analysis of musical composition of L. Mazel are the methodology basis of comparing the lexical (verbal and musical) structural units. The scientific novelty of the article consists of the consideration of a question about expressiveness of verbally-voice constituent of the dramatic performance. The novelty things are: the accent on the rhythmical organization of the verbal speech; the extrapolation of music expressive facilities into the situation of the dramatic performance.

Conclusions. The principles, which draw theatrical art closer to musical one, are the existence of a mediator between the author and recipient; processuality as an immanent quality. The mean of improving the artistic expressiveness of the process-speech side of the performance is the extrapolation of various types of music speech's rhythmical organization and their intonation contents.

Keywords: music art; theatre dramatic art; processuality; expressive means; a verbal text; a rhythm.

П остановка проблеми. Основним завданням сучасного театру $\epsilon$ духовний розвиток суспільства та впровадження справжніх ціннісних орієнтирів. I майстерність театральних митців є найдієвішим інструментом цього покликання. Отже, стаття присвячена проблемі оновлення та вдосконалення творчого арсеналу акторів-виконавців, обгрунтуванню спільних іманентних властивостей музичного й театрально-драматичного видів мистецтва як потенційної бази пошуків виразності просодійного втілення літературно-драматургічної основи вистави.
Театрально-драматичне мистецтво - важлива частина духовного життя суспільства. Демократичність і доступність для сприйняття, сила впливу на глядачів, глибина і проблем, яких торкаються в драматичних виставах - все це актуалізує питання функціонування театрального мистецтва в сьогоднішніх непростих реаліях. Наступ масової культури та комерціалізація усіх боків життя суспільства роблять необхідним оновлення театрально-драматичного мистецтва через пошук нових художніх ідей та відповідних виразних засобів. Пошук таких може здійснюється у площині двох складових 
драматичної вистави - літературно-драматургічної основи та зорового ряду. Відповідно до цього актуальним також $є$ удосконалення акторського просодійного втілення літературно-художнього тексту.

Одним із методів розгляду поставленої проблеми, що кореспондує з сучасною тенденцією використання міждисциплінарних зв'язків, $\epsilon$ використання результатів музикознавчих та літературознавчих досліджень. Проте літературознавче вивчення виразності художнього тексту не пов'язується з проблемами інтерпретації, розгляд виразних та інтерпретаційних можливостей музичного ритму й інтонації в проекції на вербальний художній текст практично відсутні. Тож у статті обгрунтовується потенційна інформаційна база для дослідження не вивчених проблем сценічної мови та іiї інтерпретації.

Пошук нових засобів виразності драматичної вистави пов'язаний із практичними завданнями удосконалення театрально-драматичного мистецтва i професійного становлення майбутніх акторів і режисерів.

Аналіз основних досліджень і публікацій. Вивчення взаємозв'язків театрально-драматичного i музичного мистецтв ставить у центр уваги питання переведення драматургічного тексту в сценічну мову вистави, просодійної виразності та відповідності сценічній дії. На початку ХX ст. ця проблема була предметом зацікавленості багатьох теоретиків та практиків театрального мистецтва. В ̈̈х роботах розглядались різні аспекти організації художньої мови - ритмічна організація, наголоси логічні та художні, питання інтерпретування тощо. Проблематика даної статті цілком відповідає літературо-центристській гілці театрознавства. В постмодерністську епоху вивчення вербальнопросодійної складової театральної вистави не посіло належного місця в роботах українських та інших вчених. Найближче до зазначеної проблематики стоять праці українського дослідника М. Гіршмана [4; 5; 6]. Його монографії та публікації присвячені дослідженню ритму художнього слова як шляху осмислення художньої цілісності твору. В аспекті вивчення часових особливостей вербально-звукової складової драматичної вистави, специфічних просодійних засобів розкриття образності останньої, інтерес становлять і фундаментальні дослідження питань інтонування в художньому тексті Н. Свєтозарової
[11]. Останнім часом питанню виразного членування художнього тексту присвячені роботи Н. Бар'ядаєвої [2] й А. Павлової [8]. В літературознавчих дослідженнях Л. Раднаєвої [10] показані засоби формування висловлювання, передачі інформації, емоційного стану та ін.

Мета статті - 3'ясувати спільні принципи функціонування музичного та драматичного творів, обгрунтувати їх як потенційну базу вдосконалення художньої виразності просодійної складової драматичної вистави; довести можливість використання виразності музичної мови в організації художньої цілісності драматичної вистави.

Виклад основного матеріалу дослідження. Постановка зазначеної проблеми потребує виявлення спільних принципів, що є підгрунтям наступних міркувань про використання практичних методів організації музичного твору в просодійному втіленні літературнодраматургічного тексту.

Етимологія терміну “принцип” походить від поняття “початок” або “основні положення”. За опорне візьмемо розуміння “принципу" I. Ньютоном: це ствердження, що сформоване на основі експериментів або спостереження за будь-яким об' єктом і використовується в значенні “початок”, відправний пункт для наступних висновків ${ }^{1}$ [9]. У випадку співставлення музичного й театрального мистецтв очевидними в якості такого роду принципів $\epsilon$ : герменевтична природа та процесуальність як іманентні якості розглядуваних видів мистецтва.

Авторський текст і драматичного, і музичного твору існує у вигляді умовних знаків - букв чи нот, які є носіями певного художнього змісту. Переведення умовних знаків запису у художні ідеї драматичного або музичного твору реалізуються в художньо-творчій діяльності виконавців акторів або музикантів. Саме вони (виконавці) взаємодіють 3 авторським текстом, тож зміст і музичного, і драматичного творів не може бути реалізований поза переломленням через їх психіку. Очевидно, що рівною мірою і для музичного мистецтва, і для театральнодраматичного важливим $\epsilon$ виконавецьінтерпретатор: в його інтерпретації авторський твір буде сприйнятим слухачами або глядачами.

Необхідна наявність виконавця-інтерпретатора активізує проблему герменевтики у виконавстві

\footnotetext{
${ }^{1}$ Таким образом, “принцип” для Ньютона отличается от утверждения тем, что он служит основой, началом на котором держатся последующие утверждения. Этот подход довольно хорошо соотносится с происхождением слова “принцип” - лат. Principium - “первый”. Следовательно, для Ньютона “принцип” - это “первое утверждение”, приобретённое из опыта, являющееся фундаментом, на котором строятся дальнейшие (“вторые”, “третьи” и т.д.) утверждения" [9].
} 


\section{ПРОСПІЛЬНІПРИНЦИПИ ТЕАТРАЛЬНОГО ТАМУЗИЧНОГО МИСТЕЦТВ}

[3; 13]. 3 одного боку, складові герменевтики пояснення та інтерпретування змісту авторського тексту як ідеального об'єкту - відсилають до тезаурусу актора (музиканта-виконавця); $з$ іншого - реалізація інтерпретації текстових елементів і організація художнього цілого пов'язані 3 комплексом професійних навичок. Якщо перше завдання не може бути вирішено тільки в процесі професійних занять, то накопичення професійних навичок складає зміст професійного навчання та виконавської практики.

У структурі професійних навичок музиканта та актора необхідно виокремити дві групи. До першої віднесемо ті технологічні навички, що, безсумнівно, різняться в музичному виконавстві та акторстві. Професійні навички другої групи (зокрема, навички прочитання тексту художнього твору як духовно-смислового об'єкту) значно зближують ці види виконавської творчості на інтелектуально-художній основі. Тож зазначені професійні навички кореспондують між собою. Основою для такого співставлення $\epsilon$ іманентні властивості музики та театрально-драматичного мистецтва. Це не тільки герменевтична їх природа, а й особливо - процесуальність, що походить від належності (повної чи часткової) до часових видів мистецтва.

Процесуальність, як іманентна властивість видів мистецтва, що порівнюються, породжує подібні проблеми ритмічної організації музичного твору або театральної вистави в часі, тобто питання форми. У музичному мистецтві проблеми формотворення розроблені достатньо повно й детально. Вивчені й формотворчі властивості окремих елементів музичної мови гармонії, фактури, ритму, а також їх формотворча дія на різних масштабних рівнях - від мотивів та фраз до композиційного ритму форми твору в цілому. Це значний потенціал смислової наповненості виконавської інтерпретації. Поперше, тому що ритм, як виразний засіб, здійснює значний вплив на слухача через співвіднесеність з біологічними ритмами усіх живих організмів. Прикладом сказаного може слугувати фінал Сьомої фортепіанної сонати С. Прокоф'єва, де всі елементи музичної мови підкорені наступальній енергії ритму і майже втрачають самостійне виразне значення. По-друге, тому що ритм організує процес розвитку, вбираючи в себе всі елементи музичної мови, які без ритму не існують. І в цьому його подвійна організуюча роль. Сказане справедливим $\epsilon$ і для ритму у вузькому розумінні, і для ритму в широкому смислі слова,

2 Поняття ритму в широкому смислі слова включає такі складові, як метр і темп. тобто для процесу формотворення на всіх масштабних рівнях організації художньої цілісності.

Дослідження ритмічного фактору в театральному мистецтві може відбуватись у двох площинах. Це: 1) ритм сценічної дії загалом, що виводить дослідника на рівень формотворення всієї драматичної вистави; 2) проблеми виконавської організації частини художнього твору, а саме звукової тканини, яка послідовно розгортається. В обох випадках очевидно, що основою і того, й іншого є літературна складова. Тому пошуки виразності ритму формотворення необхідно шукати у співвідношенні вербальних елементів та способів їх організації. За думкою М. Харлапа, “В любой прозаической речи мы можем отличать от грамматического, собственно языкового строения произносимую и звучащую ритмическую форму (фразировочную, интонационную, артикуляционную), в какой-то мере сближающуюся с музыкой, и прямо связывающую с ней словесный текст в вокальной музыке. Но если в письменной интеллектуальной речи ритмическое членение отклоняется от синтаксического только под влиянием физиологических условий произношения, то в устной эмоционально окрашенной речи ритмическая форма играет самостоятельную роль, часто более значительную, чем роль синтаксических норм" $[12,58]$.

Відсутність вказаної чіткої ритмічної² регламентації прозаїчного тексту відкриває великі можливості для виконавського прочитання драматичної вистави. Якщо співвідношення вагомості звуків у тактовій системі музичної ритміки характеризують метр (тобто безперервну канву руху, що є найпростішим засобом об'єднання), то літературному тексті співвідношення вагомості, наголос слугують “...для выделения в речевом потоке слов и, следовательно, связано со смысловым членением речи" $[12,62]$. Смислове членування мови організується не тільки акцентуванням, а й паузами між інтонаційно-смисловими одиницями. Їх конфігурація виконує визначальну роль у формуванні ритму прози, тому “... особенности метрической организации выступают как художественное задание, которое в прозаической речи (в отличие от стихотворного размера) не может быть осознано в виде нормативной теории" $[12,56]$.

Ці структурні властивості мови художнього тексту спонукають до смисло-акцентного, аналізу, що є аналогічним музичному; до сприймання 


\section{ПРОСПЛЬНІПРИНЦИПИТЕАТРАЛЬНОГО ТАМУЗИЧНОГО МИСТЕЦТВ}

тексту п’єси як своєрідної звукової “партитури”, що не тільки характеризує властивості прозаїчного тексту, а й складає музичносемантичний потенціал вистави. Хиткість і мінливість співвідношень синтаксичної структури фрази, граматичних формул та смислоакцентного, ритмічного членування складає можливий потенціал виразних засобів драматичної вистави, потенціал практичних режисерських пошуків і акторських інтерпретацій.

Ритмо-смисловий аналіз просодійних можливостей літературної основи драматичної вистави потребує, того різновиду слуху, який А. Кудряшов називає "музично-смисловим" [7, $10]$.

Шлях пізнання смислу озвученого тексту (музичного або вербального), досягнення його необхідної виразності, передбачає “смислове наповнення” граматичних структур, тому що всі закономірності внутрішньої побудови, ієрархії елементів будь-якої мови не відміняють його призначення - передачі думок-ідей [7]. В сучасному розумінні ролі структурнограматичних одиниць, як засобу передачі художньої думки, позиції музикознавців та лінгвістів збігаються. 3 одного боку, видатний лінгвіст К. Ажеж відзначав, що у природній мові “... синтаксис не является самоцелью ... Мы говорим вовсе не для того, чтобы применять и иллюстрировать правила грамматики” [1, 202]. 3 іншого боку, музикознавці все частіше висловлюють подібну за суттю думку про призначення музики - бути зрозумілою.

Отже, у проблемі вдосконалення методів роботи над художнім твором на перший план виходить семантичний аспект вивчення тексту як музичного, так і драматичного твору. Важливим видається те, що знак (слово або звук) є носієм емоційної виразності, відображає зміни психічних станів, моделює кульмінації тощо.

Висновки. Характерні властивості, що зближують театральне й музичне мистецтва, герменевтична природа та процесуальність. Ці спільні риси є основою для постановки наступних проблем: необхідності дослідження виразних можливостей літературної складової драматичної вистави в її просодійному втіленні; інтерпретації семантичного значення окремих елементів авторського тексту; встановлення аналогій музичних та вербальних ритмо-структурних мовленнєвих одиниць; організації звукової ритмічної форми - фразувальної, інтонаційної, артикуляційної; спрямованості цих проблем на розкриття прихованого смислу художніх творів.

Перспективи подальших розвідок полягають у дослідженні інтерпретаційних можливостей літературної основи драматичної вистави, у вивченні музично-смислового відчуття як основи режисерської “партитури” вистави, у вирішенні практичних завдань виховання молодих акторів.

\section{ЛІТЕРАТУРА}

1. Ажеж К. Человек говорящий: Вклад лингвистики в гуманитарные науки / Клод Ажеж [пер. с франц. Б. П. Нарумов]. - М.: Едиториал УРСС, 2003. - $304 \mathrm{c}$.

2. И. Барьядаева Н. Р. Пауза в звучащем художественном тексте / Н.Р. Барьядаева // Международный научно-исследовательский журнал. - Улан-Удэ: Бурятский государственный университет, 2016. - вып. 4 (46). - Ч.4. - С.1820.

3. Герменевтический круг [Электронный peсурс]. - Режим доступа: http://ru.wikipedia.org. - [Дата обращения 21 октября 2017].

4. Гиршман М. Ритм художественной прозы / М. Гиршман. - М.: Сов. писатель, 1982. - 366 с.

5. Гиршман М. Анализ литературного произведения: что мы анализируем и интерпретируем / М. Гиршман // Поетика художнього твору та проблеми його інтерпретації. - Дрогобич, 2002. - С. 22-36.

6. Гиршман М. Литературное произведение: теория художественной целостности / М. Гиршман. - 2-е изд., доп. - М.: Языки славянских культур, 2007. - 500 с.

7. Кудряшов А. Теория музыкального содержания. Художественные идеи европейской музыки XVII - XX вв.: учебное пособие / А. Кудряшов. - 2-е изд. - С.-Пб.: Лань, 2010. $432 \mathrm{c}$.

8. Павлова А. В. Интерпретация акцентной структуры высказывания при восприятии письменной речи / A.В. Павлова // Acta linguistica Petropolitano. Труды Института лингвистических исследований Российской академии наук. - Т.III. - Ч.3. - С.-Пб., 2007. - С. 65-117.

9. Принцип [Электронный ресурс]. Режим доступа: http://ru.wikipedia.org/wiki/. - [Дата обращения 21 ноября 2017].

10. Раднаева Л. Д. Просодическая характеристика речи / Л. Д. Раднаева // Вестник Бурятского государственного университета. - Улан-Удэ, 2013. - №10. - С. 59-61.

11. Светозарова Н. Д. Интонация в художественном тексте / Н.Д. Светозарова. - С.-Пб.: изд. С.Петербургского ун-та, 2000. - 180 с.

12. Харлап М. Тактовая система музыкальной ритмики / М. Харлап // Проблемы музыкального 
ритма: сб. статей/ сост. В.Н. Холопова. - М.: Музыка, 1978. - 48-104.

13. Шлейермахер Ф. Герменевтика / Ф. Шлейермахер [пер. с нем. А. Л. Вольский; науч. ред. Н.О. Гучинская]. - С.-Пб.: Европейский Дом, 2004. - 242 с.

\section{REFERENCES}

1. Azhezh, K. (2003). Chelovek govorjashhij: Vklad lingvistiki v gumanitarnye nauki [The person speaking: The contribution of linguistics to the humanities]. Moskva: Editorial URSS, 304 p. [in Russian].

2. Baraidaeva, N.R. (2016). Pauza v zvuchashhem hudozhestvennom tekste [Pause in sounding artistic text]. International Research Journal. Ulan-Udje: Burjatskij gosudarstvennyj universitet, issue 4 (46), part 4, pp. 18-20. [in Russian].

3. The hermeneutic circle. Available at: $<\underline{\text { https: } / /}$ ru.wikipedia.org/> (Accessed 21 January 2017). [in Russian].

4. Hirschman, M. (1982). Ritm hudozhestvennoj prozy [Rhythm of artistic prose]. Moskva: Sov. pisatel, 366 p. [in Russian].

5. Hirschman, M. (2002). Analiz literaturnogo proizvedenija: chto my analiziruem $i$ interpretiruem [Analysis of the literary work: what we are analyzing and interpreting]. Poetika khudozhnogo tvoru ta problem yogo interpretatsii. Drogobych, pp. 22-36. [in Russian].

6. Hirschman, M. (2007). Literaturnoe proizvedenie: teorija hudozhestvennoj celostnosti [Literary work:
Theory of artistic integrity]. 2nd ed. Moskva: Yazyki slavyanskikh kultur, 500 p. [in Russian].

7. Kudryashov, A. (2010). Teorija muzykalnogo soderzhanija. Hudozhestvennye idei evropejskoj muzyki XVII - XX vv.: uchebnoe posobie [Theory of musical content. Artistic ideas of European music of the XVII - XX centuries: teaching guide]. Saint Peterburg: Lan, 432 p. [in Russian].

8. Pavlova, A.V. (2007). Interpretacija akcentnoj struktury vyskazyvanija pri vosprijatii pismennoj rechi [Interpretation of the emphasis structure of the utterance in the perception of written speech]. Trudy Instituta lingvisticheskikh issledovaniy Rossiyskoy akademii nauk. Saint Peterburg, Vol.3, part 3, pp. 65-117. [in Russian].

9. A principle. Available at: $<$ http://ru.wikipedia.org/ wiki/> (Accessed 21 February 2017). [in Russian].

10. Radnaeva, L.D. (2013). Prosodicheskaja harakteristika rechi [Prosodic Speech Characteristics]. Vestnik buryatskogo gosudarstvennogo universiteta. Ulan-Ude, issue 10, pp. 59-61. [in Russian].

11. Svetozarova, N.D. (2000). Intonacija v hudozhestvennom tekste [Intonation in the literary text]. Saint Peterburg: izd. S.-Peterburgskogo universiteta, 180 p. [in Russian].

12. Harlap, M. (1978). Taktovaja sistema muzykalnoj ritmiki [The time system of musical rhythm]. Problemy muzykalnogo ritma. Moskva: Muzyka, pp. 48-104. [in Russian].

13. Schleiermacher, F. (2004). Germenevtika [Hermeneutics]. Saint Peterburg: Evropeyskiy dom, 242 p. [in Russian].

Стаття надійшла до редакції 12.06.2018

\section{G58080}

"Хто хоче зрушити світ, нехай зрушить себе! "

$$
\begin{array}{r}
\text { Сократ } \\
\text { давньогрецький ббілособ }
\end{array}
$$

“Dля того, щоб прийти до справжнъого знання, треба спочатку відчути сумніви”.

Apicmomesь давньогреиький вчений-енииклопедист, білособ

“Ми знаходимо в житті лише те, що самі вкладаємо в нього”.

Ральбб Волдо Емерсон американсьқий есеїст, поет і білособ

"Не Бійтеся життя. Товірте, що життя варте того, щоб його прожити, - $і$ ваша віра допоможе вам втілити ие твердження в реальність".

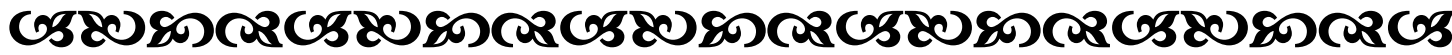

